\title{
REVIEW PAPER \\ The end of regressive evolution: examining and interpreting the evidence from cave fishes
}

\author{
A. Romero* and S. M. Greentt \\ *Department of Biological Sciences, Arkansas State University, P.O. Box 599, State \\ University, AR 72467, U.S.A. and $\dagger$ Department of Biology, University of Miami, \\ P.O. Box 249118, Coral Gables, FL 33124, U.S.A.
}

(Received 5 May 2004, Accepted 18 March 2005)

\begin{abstract}
The evolution of hypogean fauna in general and hypogean fishes in particular has been controversial. Explanations regarding the reduction or loss of phenotypic characters such as eyes and pigmentation range from neo-Lamarckism to neutral mutations, with 'regressive evolution' being a catch-all characterization for such processes. The assumptions required for special evolutionary mechanisms underlying the evolution of cave dwellers have been based on generalizations about the animals and their environments drawn from relatively few observations. The evidence offered for notions such as pre-adaptation of colonizing fauna and the purported impoverished nutrients in all caves is examined and it appears that the generalizations cannot be supported. Some major accomplishments in field and laboratory studies of hypogean fishes are summarized, including work highlighting developmental phenotypic plasticity. At the end, it is argued that evolution of hypogean fauna can be explained by well-known mechanisms within the current context of evolutionary biology.

(C) 2005 The Fisheries Society of the British Isles
\end{abstract}

Key words: evolutionary biology; hypogean fishes; troglomorphisms; phenotypic plasticity; preadaptation; cave ecology.

Analysis of the biospeleological literature concerning the evolutionary biology of cave dwellers reveals conceptual problems that have plagued the development of biospeleology within the framework of neo-Darwinism (Culver \& Wilkens, 2000). That literature is littered with views that explicitly or implicitly imply 'regressive evolution' (Borowsky \& Wilkens, 2002). This notion encompasses scenarios that include accidental and disadvantageous entrapment of animals, colonization by those that are somehow 'pre-adapted,' and selection disfavoring all but a very limited set of attributes that enhance survival in a harsh and nutrient limited environment. These scenarios represent an orthogenetic view of evolution, one that suggests regressive evolution leads to a putatively less complex or advanced set of characteristics as a result of directional selection for the bare essentials. The loss of eyes and pigmentation in cave environments are an oft-cited example from a suite of traits labelled troglomorphic.

\#Author to whom correspondence should be addressed. email: steven.green@miami.edu 
First a brief outline of the history of interest in hypogean (subterranean) fishes and their evolution is presented, followed by summarizing and reviewing the evidence behind each of these foundations for the 'regressive evolution' view: 1) the colonization process, 2) pre-adaptations, 3) the nature of the cave environment, and 4) troglomorphisms. This review leads to the conclusion that the available evidence does not support the assumptions required for the 'regressive evolution' argument. In its place is offered a broader view that is more consistent with the evidence and with evolutionary biology as it applies generally. This perspective does not invoke unusual evolutionary processes requiring special assumptions for exploiting cavernicolous niches; it also emphasizes phenotypic plasticity as playing a major role in the evolution of hypogean fishes.

\section{EARLY PUBLICATIONS}

The first reference to hypogean (cave and phreatic) fishes was published in China in 1541 and confirmed by Chen et al. (1994). European pre-Linnaean references to alleged blind cave fishes have never been confirmed (Romero, 1999; Romero, 2000; Romero \& Lomax, 2000, for a detailed discussion of each one of them). James Ellsworth DeKay (1842) described the Northern cavefish, Amblyopsis spelaea DeKay, 1842, from Mammoth Cave, Kentucky, in the first scientifically acknowledged report of a blind cave fish species (Romero, 2002).

That discovery in the creationist environment of its time spurred publication of anatomical descriptions seeking to explicate the blindness. The crux of the issue was whether individual cave fish were actually surface fish that had become blind and depigmented after invading the cave due to the lack of light and its influence on the developmental process or if they had been created to live in its darkness. To resolve this point, Jean Louis Rodolphe Agassiz proposed raising these fish under conditions of both light and darkness to see whether or not the environment directly influenced the development of their eyes (Agassiz, 1847, 1851).

Charles Darwin was not sure what to make of these creatures. In the first edition of On the Origin of Species by Means of Natural Selection (Darwin, 1859), he interpreted the unusual characteristics of cave animals employing a combination of selectionist and neo-Lamarckian use and disuse arguments to explain blindness, depigmentation, and the enhancement of sensory organs, shifting even more towards neo-Lamarckian explanations by the third edition (Darwin, 1861) (for a history of the study of hypogean fishes see Romero, 2001b).

This era of American neo-Lamarckism influenced by Darwin and continuing for the remainder of the 19th century was followed by one dominated by the discovery of many new cave fish species from all over the world. These new species, as well as new species of fishes of all kinds, were described primarily by investigators from colonial powers exploring lands new to them. The bizarre appearance of most of the cave fish led to their being assigned to new genera in conformity with the prevailing typological (essentialist) species concept.

The discovery in Mexico of blind cave populations of the surface-dwelling Mexican tetra, Astyanax fasciatus (Characidae) (Cuvier, 1819), was interpreted within the population viewpoint of the New Synthesis to change the prevailing typological view. These fish proved to be so genetically similar to their surface 
(eyed, pigmented) forms (Avise \& Selander, 1972; Kirby et al., 1977) that the typological notion of blind cave fishes as always being a different genus from their surface ancestors could not be sustained (Romero, 1986).

This neo-Darwinian view of cave fishes dominated until the 1950s and 1960s when neo-Lamarckian views (orthogenesis, organicism, and finalism) and jargon (epitomized by the term 'regressive evolution') were reintroduced by European biologists to explain elements of cave organism evolution, particularly in fishes. More than 2200 papers, books, and abstracts have been published, with the rate steadily increasing from about 5 per year before 1940 to today's rate of about 100 annually, including initial descriptions of 86 species of blind cave and phreatic fishes. Even with this abundant literature, the debate on the evolutionary history of hypogean fish remains intense.

\section{WHY DO FISH COLONIZE CAVES?}

Colonization of caves as a precursor to the evolution of hypogean forms or species is generally viewed either as accidental (entrapment or refugium) or as actively advantageous, with the potential advantages including, for example, environmental stability, exploitation of new niches, and protection from predation.

\section{ACCIDENTAL ENTRAPMENT}

Biospeleologists have espoused the idea that caves are colonized by accident or some other very unusual circumstance (Holsinger, 2000). This notion derives in part from the mistaken generalization examined in the next section that most caves are harsh environments with impoverished resources. Part of this argument is that once the organisms get into the hypogean environment, the only reason they stay there is that they become 'trapped' (Wilkens, 1979; Langecker, 1989), but there is no empirical evidence supporting this supposition.

Hypogean and the epigean aquatic environments are contiguous most of the time. When potential colonizers reach the hypogean habitat, no permanent discontinuity prevents them from returning to their original habitat ( $c f$. Romero et al., 2002b), although perhaps not immediately in the case of episodic and rapid flooding. Molecular evidence also indicates that cave colonization need not be 'accidental.' For example, Dowling et al. (2002) and Strecker et al. (2003), provide genetic analyses suggesting that at least some of the troglomorphic populations in Mexico may have arisen from separate cave invasions. If that is the case, it is unlikely that cave colonization by $A$. fasciatus was the result of a fortuitous entrapment, since such a serendipitous event would not be likely to occur repeatedly in the same geographical area.

The accidental-entrapment hypothesis reflects the conventional wisdom in biospeleology, implicitly simultaneously accepting the view that not all animals so entrapped will survive but rather favoring those species with preadaptations. Although this scenario cannot be ruled out for every instance of cave colonization, it clearly does not have the kind of general validity that applies to colonization when there is environmental discontinuity (e.g., terrestrial organisms carried by wind or sea to islands and entrapped there). 


\section{CLIMATIC REFUGIA}

The climate-relict model of cave colonization notes that cool moist environments occurred just south of the glacial maxima. These zones were putatively occupied by species thriving in this climate (mainly invertebrates) that did not fare well in the drier and more variable areas further south. As glaciers retreated 'these species became progressively restricted to the cool, moist interiors of caves, sinkholes, deep wooded ravines, and cool forest floors at higher altitudes' (Holsinger, 2000, p. 403). According to this line of thought, when warming extinguished the epigean populations, the hypogean ones remained isolated and consequently ready to evolve very quickly into obligate cave-dwelling species.

One of the classical objections to this hypothesis is that it does not explain the origin of hypogean fauna in the tropics. This objection has been countered by saying that although the tropical regions did not experience the temperature variations of the temperate areas of the world, they were subject to major variations in rainfall; caves may have served as refugia for organisms requiring a more constant wet or very moist environment (Humphreys, 1993; Trajano, 1995). The climatic-relict hypothesis, being tied to glaciation, cannot, however, explain current events of cave colonization (Romero et al., $2002 b$ ). Also inconsistent with this model are results from molecular clock studies that have shown many cave species became hypogean well before the advent of the more recent glaciations. Chakraborty \& Nei (1974), for example, calculated the time for divergence between the cave and river populations of $A$. fasciatus as between 525000 and 710000 years, consistent with geological data on formation of the caves where these fish are found today. Therefore, although conventional wisdom is that most troglomorphic organisms are the result of climatic shifts (Holsinger, 2000), this view is not empirically supported in that the literature cited in this section is inconsistent with such speculation.

\section{ADAPTIVE SHIFT}

Active exploitation of new niches and exploitation of resources with diminished competition in a hypogean environment is suggested to have exerted such strong selective pressure on 'preadapted' ancestral invaders that their population quickly diverged from their epigean ancestors with which they were still sympatric. This scenario is attractive in that there is some resemblance to well-documented allopatric adaptive radiation (as in Darwin's finches). This adaptive-shift hypothesis on cave colonization does not, however, take account of the large number of troglobites in which related organisms are unknown from the epigean environment (for examples among fish see Romero \& Paulson, 2001); in some cases new families have been erected for troglobites that lack any obvious affinities to epigean species (Yager, 1994). The proponent of this model (Howarth, 1973, 1981) works on lava tube caves in Hawaii where the characteristics he describes may be common for that habitat and location, but there is no evidence supporting general applicability of the adaptive-shift model. 


\section{ACTIVE ENTRY}

Similar to the adaptive shift hypothesis, active entry is suggested to confer an advantage to individuals occupying the epigean environment. This model does not, however, require virtually instantaneous genetic isolation from the ancestral hypogean population. It furthermore does not assume that the cave environment is particularly harsh, so that invaders can become colonists without a set of preadaptations to surviving in a putatively inhospitable habitat. It suggests that ordinary natural selection will favor individuals whose behaviour removes them from the epigean habitat when it is disadvantageous to be there. Is there evidence for an example of active entry?

Romero (1984, 1985a) carried out field studies at a pond in Costa Rica that receives water from a phreatic source. An assemblage of about $120 \mathrm{~A}$. fasciatus lived in that pond. These fish were morphologically identical to epigean tetras of the same species found in nearby ponds, i.e., with full eyes and pigmentation. When floating food was dropped onto the surface of the water, the fish almost without exception pushed that food to the subterranean habitat where it was then consumed. Surprisingly, they also entered the subterranean flow of water at dusk. A series of field observations and manipulations indicated that pushing food into the subterranean cavity and occupying that cavity at night served to reduce predation by the locally abundant echolocating fishing bat, Noctilio leporinus (Linnaeus, 1758), which could detect surface ripples caused by eating or by swimming near the oxygen-rich surface. Entering hypogean waters is therefore potentially advantageous to these epigean fish.

The question then remained as to whether this cave-entering behaviour is a species characteristic and, in that sense, a pre-adaptation to cave dwelling. $A$. fasciatus individuals from this pool, connected to the subterranean cavity, and from a nearby pool, one without any connection to the hypogean waters, were examined in the laboratory. Fish from both sources were separately kept in aquarium tanks under a 12-h day/12-h night cycle for 9 months and then tested for preferences to shaded or illuminated halves of larger tanks. The fish from the connected pool still preferred to move into the shaded area when the dark half of the cycle started, a response not witnessed among the fish from the open pool.

Taken together, these results suggest not only that A. fasciatus was using the underground pool as a shelter from bat predation, but also that active entry to underground waters may be a behavioural response to selective pressure, one that occurs in the absence of any morphological characteristics typical of cave dwellers and one that is not a general behavioural preadaptation of the species.

The idea of active colonization has also been proposed for ice caves in temperate regions (Racovita, 2000). Other studies also suggest that the fauna found in some caves, such as those that are chemoautotrophic, may be the result of multiple active colonization events over time (Sarbu, 2000).

Moving into caves may help avoid predation in $A$. fasciatus and there may be other advantages to active entry for other species, but are there characteristics of some fish species that make them more likely to be successful hypogean colonizers after entry than others? 


\section{'PRE-ADAPTATIONS' TO THE HYPOGEAN ENVIRONMENT}

Christiansen (1992, p. 464) writes 'There is general agreement that pre-adaptation (or exaptation) is crucial for entrance into caves' and Holsinger (2000, p. 400) notes 'There is a consensus among biospeleologists that troglobites are ultimately derived from pre-adapted epigean propagules or founders that live in either terrestrial or aquatic environments.'

The belief that pre-adaptation is an essential precursor to cave occupancy derives in part from the view that the attributes selected for success in the epigean environment will not in general be appropriate for cave dwelling. Weber (2000, p. 110), for example, asserts that 'successful colonists have appropriate morphological, physiological and ethological adaptations that enable them to survive and reproduce in the cave habitat.' In one sense this must, of course, be true. It also implies, however, that the successful cave colonizers are somehow phenotypically different from other epigean species that do not thrive when they enter hypogean waters. In other words, what at first appears to be a truism is in fact an argument for pre-adaptations.

What evidence supports the notion that pre-adaptations are necessary for colonizing the hypogean environment? Holsinger (2000, p. 400) offers nine references to substantiate what he calls a widespread agreement on this matter; these sources simply make parallel assertions of this view, thereby making Holsinger's claim of agreement true, but none offer compelling empirical evidence. As noted in the next section, a very large proportion of cave organisms don't even exhibit troglomorphic characters, let alone 'pre-adaptations' to the hypogean environment.

In a survey of the biospeleological literature, A. Romero \& K.M. Paulson (unpubl. data) found that 'pre-adaptation' for the hypogean environment is used by various authors to convey: a) hyperdeveloped nonvisual sensory organs, b) low metabolism, and c) nocturnal habits (Holsinger, 2000; Langecker, 2000). These features would be advantageous for obvious reasons - environmental information not relying on vision, undemanding energy requirements in the face of a putatively impoverished environment, and a full behavioural repertoire that occurs in darkness. To test the pre-adaptation hypothesis, A. Romero \& K.M. Paulson (unpubl. data) grouped the 86 troglomorphic species of fishes into their 18 families and looked for 'pre-adapted' characters in those families (Table I). Since the putative ancestors for each troglomorphic species cannot, in most cases, be determined with reasonable certainty (many of those ancestral species are probably extinct), characters at the family level were used. In only 10 of the 18 fish families containing troglomorphic members can these "pre-adaptive' features be viewed as characterizing the family.

Let's examine two well-known examples of hypogean fish in the context of 'pre-adaptations.'

The most studied cave fish is undoubtedly $A$. fasciatus in its troglomorphic form (roughly one fourth of all papers published on 86 species of troglomorphic fishes are on this species). The surface form, its epigean ancestor, is comparably well-studied, but a 'pre-adapted' feature of this morph has not been suggested or identified. No structures that would be critical for the survival of this fish species in the hypogean environment are known. Schemmel (1967) found that 'There is 
TABLE I. List of fish families with troglomorphic representatives. If putatively 'preadapted' features (namely hyperdeveloped nonvisual sensory organs, low metabolism, and nocturnal habits) are reported in a family, that family is listed in the column of "preadapted' families. Families without these features are in the second column. Numerical entries are the number of troglomorphic species in each family. Families are listed in the order suggested by Nelson (1994)

\begin{tabular}{lrlr}
\hline 'Pre-adapted' families & & Non-'pre-adapted' families & 18 \\
\hline Balitoridae & 15 & Cyprinidae & 1 \\
Ictaluridae & 4 & Cobitidae & 2 \\
Siluridae & 2 & Characidae & 3 \\
Claridae & 3 & Loricariidae & 7 \\
Pimelodidae & 7 & Bythitidae & 1 \\
Trichomycteridae & 3 & Poecilidae & 4 \\
Astroblepidae & 2 & Eleotridae & 4 \\
Sternopygidae & 1 & Gobiidae & \\
Amblyopsidae & 5 & & 40 \\
Synbranchidae & 4 & & \\
Total & 46 & Total & \\
\hline
\end{tabular}

no evidence for degenerative or constructive tendencies in the highly developed systems of neuromasts, in the nasal organs and in the labyrinths of the cavernicolous forms compared to the epigean ancestor Astyanax. There is an increase, however, in number and extension of taste buds.' Furthermore, the well-developed neuromast system in $A$. fasciatus is not unique to that species but is a generalized feature among characids. Mexican populations that have been sampled do not show increased development of the laterosensory system compared to other Astyanax or to other characids. On the contrary, some aspects of the laterosensory system have been lost, apparently a paedomorphic feature associated with small size at maturity (S. Weitzman, pers. comm.).

A. fasciatus is therefore believed to have been a successful colonizer not because it has a 'pre-adaptation' such as a specially developed lateral line, but rather because it is a generalist. Its ecological adaptability also helps explains its broad distribution as well as the fact that it is one of the two species of the $c .900$ species of characids to have ever colonized the cave environment (the other is Stygichthys typhlops Brittan \& Böhlke, 1965, whose phylogenetic relationships are rather obscure).

The Texas toothless blindcat, Trogloglanis pattersoni Eigenmann, 1919, an Ictalurid catfish, is found in deep phreatic layers of the Edwards Aquifer in Texas. These waters are highly depleted of nutrients and the specimens obtained from this habitat have always shown acute signs of starvation yet, unlike most of the Ictaluridae, this species has minute rather than enlarged barbels (Langecker \& Longley, 1993). Bardach et al. (1967) showed that the barbells of ictalurids are rich in chemosensory detectors. Therefore, if the assumption made by most biospeleologists were true, hyperdeveloped sensory organs for detecting food in complete darkness would be expected to be present. For this specific case, the pre-adaptation hypothesis predicts those barbels to be larger than or at least the 
same relative size as typical of the family, yet they have been reduced, an attribute clearly inconsistent with the notion that enlarged sensory organs are required to enhance survival potential in the hypogean environment.

Paralleling these two examples, the evidence in general does not support 'preadaptation' as a requirement for cave colonization. 'Pre-adaptations' to the hypogean environment are concluded to be neither necessary nor sufficient for successful colonization.

For the notion of 'pre-adaptation' to be useful, attributes that evolved in one environment must enhance success in a second, quite different, environment. The additional implication is that the second environment, hypogean waters in our case, is one in which survival is difficult so that animals lacking those 'pre-adaptations' would be unlikely to survive. An alternate term with a somewhat different meaning, 'exaptation,' has been advanced by Holsinger (2000) to replace 'pre-adaptation' when considering the evolution of hypogean fishes. Gould \& Vrba (1982) define exaptation as 'features that now enhance fitness but were not built by natural selection for their current role.' The concept is later clarified by Gould (2002) to embrace specific structures that were previously developed for a particular role and now are being used for a different function. The implication is again that selective pressures, the cave environment, modified an existing feature, thereby enhancing success. When applied to the same characteristics as the putative 'pre-adaptations' of cave animals, it is not clear that the term 'exaptation' adds any clarity. If, on the other hand, it is meant to help elucidate origins of other features of cave animals, e.g., the reduction or loss of attributes that characterize troglomorphism, then the term seems misapplied since the troglomorphic characteristics are not, for the most part, building on attributes that occur in the hypogean ancestors.

In any case, both terms are attempting to help explain some of the characteristics of hypogean fauna and are thus integrally linked with understanding the hypogean environment.

\section{THE HYPOGEAN ENVIRONMENT: MYTHS AND REALITIES}

Only about $3 \%$ of all global fresh-water is on the surface (Marmonier et al., 1993). Fish living in the hypogean environment, that part of the biosphere found underground, inhabit caves (subterranean cavities accessible to humans) and phreatic waters (water deposits in compact rocks that can be studied only indirectly through wells), both relatively poorly known compared to surface freshwaters.

Few biologists realize that hypogean biodiversity is quite high, with Culver \& Holsinger (1992) estimating the number of troglomorphic species at 50000 to 100000 . This number is considerable given that most hypogean habitats are very limited in space, usually lack primary producers, and have not been thoroughly explored, particularly in the tropics where caves contain a very diverse fauna (Deharveng \& Bedos, 2000).

Hypogean environments include karsts, lava tubes, ice caves, and underground lakes and rivers (phreatic); some are very isolated while others form an extensive underground network with multiple connections to the epigean environment. Among those that are aquatic in nature are found fresh water, marine, 
and anchialine (with restricted exposure to open air, one or more connections to the sea, and influenced by both the marine and terrestrial ecosystems with which they interface) habitats. Anchialine habitats are common in volcanic or limestone bedrock (Sket, 1996a). Examples of anchialine fishes include species of the genus Lucifuga in Cuba and the Bahamas, Ogilbia galapagosensis (Poll \& LeLeup, 1965) from the Galápagos Islands, and Milyeringa veritas Whitley, 1945 and Ophisternon candidum (Mees, 1962) from northwestern Australia. Regardless of these differences in nature and size, all hypogean environments have one thing in common: the lack of light for most if not all of the space beyond their entrances.

The assumptions behind accidental entrapment and pre-adaptations rely on a view that hypogean environments are unwelcoming to surface dwellers and 'harsh' because they are poor in nutrients (Holsinger, 2000). Yet cave colonizers not only can find food (Ferreira \& Martins, 1999), but they also gain access to suitable breeding areas (Rogowitz et al., 2001), protection from predators (e.g., Romero, 1985a; Tabuki \& Hanai, 1999), and refugia for hibernation (Zhang, 1986). The ecological opportunities of the hypogean environment (Bellés, 1991) have permitted many taxa to undergo extensive adaptive radiations, leading to a plethora of differentiated populations and species (Hoch \& Howarth, 1999).

Although some caves in temperate regions may be nutrient poor (e.g., Poulson \& White, 1969), many caves, particularly in tropical regions, are very rich in nutrients, (Deharveng \& Bedos, 2000). Others are chemoautotrophic (Airoldi \& Cinelli, 1996; Sarbu, 2000; Sarbu et al., 2000; Hose et al., 2000) thanks to bacteria that produce organic matter by oxidizing sulfur. Both tropical and chemoautotrophic caves are usually very rich in species with some of those species having large population sizes.

Indirect evidence is typically cited to imply impoverishment. Weber (2000, p. 110), for example, claims that 'one adaptation to the low food supply is the body size of troglobitic fishes and salamanders, which are usually small in comparison to epigean relatives ...' But there is no empirical evidence that cave organisms are generally smaller than their putative ancestors. The troglomorphic sculpins of the Cottus carolinae (Gill, 1861) species group, for example, are actually larger than the surface form (G.L. Adams, pers. comm.). Even if such evidence should emerge, there are at least two alternative explanations to the nutritional impoverishment hypothesis. First, many caves have a large number of crevices that provide not only protection against potential predators but may be the only means to move from one cave to another. Thus being smaller provides a selective advantage independent of food supply. Second, as will be described in the next section, many troglomorphic characters are the product of heterochrony, and small body size is a product of that phenomenon.

If food supply is low, then the purported 'preadaptation' of low metabolic rate can be justified. But when the hypogean form of $A$. fasciatus, is examined, it is found to exhibit nearly twice the metabolic rate of its epigean form (Schlagel \& Breder, 1947). The associated increase in swimming behaviour may serve to enhance lateral line organ stimulation (Burt de Perera, 2004), perhaps compensating for the absence of visual stimuli. Several cave populations of amphipods also exhibit metabolic rates no lower than their epigean counterparts (Culver, 
1971; Gilbert \& Mathieu, 1980), demonstrating that A. fasciatus is not an aberration or unique case in this regard.

More recently Jeffery et al. (2003) examined energetic costs of shutting down eye development in blind cave Astyanax. They found that during lens development a number of signals responsible for inducing eye tissue differentiation are necessary to suppress apoptosis. In their absence, cell death leads to eye degeneration. Since considerable metabolic energy is expended by continuous generation of new retinal cells that eventually die, they conclude this is a very inefficient process inconsistent with the hypothesis that eye degeneration contributes to metabolic savings.

Given all this evidence, it is surprising how many authors continue to depict hypogean environments as nutrient-poor and then use that erroneous characterization to explain the evolution of troglomorphic characters. The generalization that the hypogean environment is nutritionally impoverished, and therefore harsh, simply does not hold. But even if not derived from 'pre-adaptations' to a 'harsh' environment, aren't there some common features of hypogean fishes?

\section{TROGLOMORPHISM AND THE NATURE OF HYPOGEAN FISHES}

Hypogean (subterranean) fauna in general and hypogean fishes in particular are usually described by having a set of characters called troglomorphisms, epitomized by blindness and depigmentation (see Table II for a list of troglomorphic characters). Although these features may, indeed, not be found together in surface-dwelling fresh water fish, they also do not characterize hypogean fish in general. Close examination of the evidence reveals the following three points.

TABLE II. Catalogue of 'troglomorphic' features. These are the characters that frequently differ from those in closely related epigean organisms. Troglomorphic organisms may display only a few, some, or all of these characters. Some characters may differ in either direction (e.g., some troglomorphic fishes display reduced metabolism, other species exhibit an increase)

\begin{tabular}{|c|c|c|}
\hline Morphological & Physiological & Behavioural \\
\hline \multicolumn{3}{|l|}{ Reduced, diminished, or lost } \\
\hline Eyes, ocelli & Metabolism & Photoresponse \\
\hline Visual brain centers & Circadian rhythms & Aggregation \\
\hline Pigmentation & Fecundity & Response to alarm substances \\
\hline Pineal organ & & Aggression \\
\hline \multicolumn{3}{|l|}{ Body size } \\
\hline \multicolumn{3}{|l|}{ Cuticles (terrestrial arthropods) } \\
\hline \multicolumn{3}{|l|}{ Scales (fishes) } \\
\hline \multicolumn{3}{|l|}{ Swimbladder (fishes) } \\
\hline \multicolumn{3}{|l|}{ Enlarged, enhanced, or exaggerated } \\
\hline Chemo- and mechano-receptors & Life span & \\
\hline Appendages & Lipid storage & \\
\hline \multirow[t]{2}{*}{ Body size } & Metabolism & \\
\hline & Egg volume & \\
\hline
\end{tabular}


1. Troglomorphism (primarily reduction or loss of eyes and depigmentation) is reported in 86 hypogean species or populations (Romero \& Paulson, 2001) whereas 115 of them are not troglomorphic (Poly, 2001). This imbalance is probably an underestimate of the actual ratio because cave fish researchers are usually focused on troglomorphic species, so it is likely that many nontroglomorphic ones are overlooked or unreported (Romero, 2001b). In hypogean fauna overall, there are fewer troglomorphic organisms than non-troglomorphic ones and the proportion is seen to generally increase at lower latitudes (Table III). If troglomorphism is linked to the putatively impoverished food availability (see Hüppop, 2000), the pattern would be the opposite because most karstic and impoverished areas are in temperate regions (see the frontispiece of Wilkens et al., 2000). Troglomorphic species in Canada, for example, would be expected, yet their absence is conspicuous (Peck, 1988).

2. Blindness and depigmentation are not found to have the same degree of expression among most species. Because Banister (1984) indicated that neoteny, the retention of juvenile characteristics in adults, is noted to result in loss of scales among fishes in general and may be associated with cave dwelling, it is also considered. Romero \& Paulson (2001), after categorizing the level of pigmentation, blindness, and scale development of troglomorphic fishes, found that only ten out of 86 species had the same level of expression of these troglomorphic characters (Table IV). The number of species expected to have the same level of troglomorphic expression of all three characters is $3 \cdot 84$, based on the actual prevalence of each of the character states taken over

TABLE III. Latitudinal prevalence of troglomorphic species. There is an increasing proportion of troglomorphic species towards the equator. Slovenia, an exception, is also almost entirely karstic. Entries are summarized from sources that are hypogean faunal surveys in selected regions of the world. Latitude is an estimate of the average for each region surveyed

\begin{tabular}{|c|c|c|c|c|}
\hline $\begin{array}{l}\text { Area/cave } \\
\text { Surveyed }\end{array}$ & $\begin{array}{c}\text { Number of } \\
\text { non-troglomorphic } \\
\text { species }\end{array}$ & $\begin{array}{l}\text { Number (and } \\
\text { percentage) of } \\
\text { troglomorphic } \\
\text { species }\end{array}$ & $\begin{array}{l}\text { Average } \\
\text { latitude }\end{array}$ & Source \\
\hline $\begin{array}{l}\text { Southern } \\
\text { Ontario, } \\
\text { Canada }\end{array}$ & 301 & $0(0 \%)$ & $50^{\circ}$ & Peck (1988) \\
\hline Slovenia & 1066 & $190(15 \cdot 13 \%)$ & $46^{\circ}$ & Sket (1996b) \\
\hline France & 4218 & $218(4.91 \%)$ & $46^{\circ}$ & Juberthie \& Ginet \\
\hline $\begin{array}{l}\text { Pennsylvania, } \\
\text { USA }\end{array}$ & 131 & $15(10 \cdot 27 \%)$ & $41^{\circ}$ & $\begin{array}{l}\text { Mohr (1953); } \\
\text { Holsinger (1976) }\end{array}$ \\
\hline $\begin{array}{l}\text { New South } \\
\text { Wales, } \\
\text { Australia }\end{array}$ & 422 & $83(16 \cdot 5 \%)$ & $33^{\circ}$ & $\begin{array}{l}\text { Thurgate et al. } \\
(2001 a)\end{array}$ \\
\hline $\begin{array}{l}\text { Northern } \\
\text { Mexico }\end{array}$ & 143 & $32(18 \cdot 29 \%)$ & $25^{\circ}$ & Reddell (1982) \\
\hline $\begin{array}{l}\text { Eastern } \\
\quad \text { Australia }\end{array}$ & 148 & $82(35 \cdot 65 \%)$ & $20^{\circ}$ & $\begin{array}{l}\text { Thurgate et al. } \\
\text { (2001) }\end{array}$ \\
\hline
\end{tabular}


TABLE IV. Expression of troglomorphisms among hypogean fishes. Character states for each species exhibiting any troglomorphism in pigmentation, eyes, or scales can be assigned to one of four categories ranging from absence (A: no expression of character, maximally troglomorphic) to full expression (D: no troglomorphism) of these three troglomorphic characters. Many species exhibit wide variation in eye size or pigmentation; the most troglomorphic form (the most cave-adapted) is the basis for the categorization that is based on descriptions in Romero and Paulson (2001). The listing order of species is based on the systematic order of their families as given in Nelson (1994)

\begin{tabular}{llll}
\hline Category & Pigmentation & \multicolumn{1}{c}{ Eyes } & \multicolumn{1}{c}{ Scales } \\
\hline A & Absent & Absent & Absent \\
B & Slight & Microphthalmic & Embedded \\
C & Mostly & Sunken & Reduced \\
D & Fully expressed & Fully expressed & Fully expressed \\
\hline
\end{tabular}

Pigment Eyes Scales

Species
Barbopsis devecchii Di Caporiacco, 1926
Caecogobius geertsi Boulenger, 1921
Caecocypris basismi Banister \& Bunni, 1980
Garra barremiae Fowler \& Steinitz, 1956
Garra dunsirei Banister, 1987
Iranocypris typhlops Bruun \& Kaiser, 1944
Phreatichthys andruzzii Vinciguerra, 1924
Poropuntius speleops (Roberts, 1991)
Sinocyclocheilus anatirostris Lin \& Luo, 1986
Sinocyclocheilus angularis Zheng \& Wang, 1990
Sinocyclocheilus anophthalmus Chen, Chu, Luo \&
Wu, 1988

Sinocyclocheilus cyphotergous (Dai, 1988)

Sinocyclocheilus furcodorsalis Chen, Yang \& Lan, 1997

Sinocyclocheilus hyalinus Chen \& Yang in Chen,

Yang \& Zhu, 1994

Sinocyclocheilus microphthalmus Li, 1989

Troglocyclocheilus khammouanensis Kottelat \& Bréhier, 1999

Typhlogarra widdowsoni Trewavas, 1955

Protocobitis typhlops Yang, Chen \& Lan, 1994

Cryptotora thamicola (Kottelat, 1988)

Nemacheilus evezardi Day, 1872

Nemacheilus starostini Parin, 1983

Nemacheilus troglocataractus Kottelat \& Géry, 1989

Oreonectes anophthalmus Zheng in Anonymous, 1981

Paracobitis longibarbatus Chen, Yang, Sket \& Aljancic, 1998

Paracobitis smithi (Greenwood, 1976)

Schistura jarutanini Kottelat, 1990

Schistura oedipus (Kottelat, 1988)

Schistura sijuensis Menon, 1987*

Sundoreonectes tiomanensis Kottelat, 1990*

Triplophysa gejiuensis Chu \& Chen, 1979
B

A

A

A

A

A

A

A

A

A

B

A

A

A

A

A

A

$\begin{array}{ll}\text { B } & \text { C } \\ \text { B } & \text { C } \\ \text { A } & \text { C } \\ \text { B } & \text { C } \\ \text { D } & \text { C } \\ \text { B } & \text { C } \\ \text { B } & \text { A } \\ \text { B } & \text { D } \\ \text { B } & \text { A } \\ \text { B } & \text { B } \\ \text { B } & \text { C }\end{array}$

$\begin{array}{ll}\text { B } & \text { A } \\ \text { B } & \text { C } \\ \text { B } & \text { A }\end{array}$

A

A

B

$\mathrm{D}$

A

A

A

B D

B D

B D

B C

B C

B A

C $\quad$ C

B A

B $B$

A $\quad$ B $\quad$ A

A $\quad$ B $\quad$ A

$\begin{array}{lll}\text { A } & \text { B } & \text { A } \\ \text { B } & \text { A } & \text { B } \\ \text { A } & \text { B } & \text { B } \\ \text { C } & \text { C } & \text { C } \\ \text { B } & \text { B } & \text { B } \\ \text { A } & \text { B } & \text { A }\end{array}$


Triplophysa shilinensis (Chu \& Yang in Chen, Yang and $\mathrm{Xu}, 1992)^{*}$

Triplophysa xiangxiensis (Yang, Yuan \& Liao, 1986)

Triplophysa yunnanensis (Yang, 1990)

B $\quad$ B $\quad$ A

Astyanax fasciatus (spp. Complex) (Cuvier, 1819)

D

A

Stygichthys typhlops Brittan \& Böhlke, 1965

Prietella lundbergi Walsh \& Gilbert, 1995

Prietella phreatophila Carranza, 1954

Satan eurystomus Hubbs \& Bailey, 1947

Trogloglanis pattersoni Eigenmann, 1919

Pterocryptis buccata $\mathrm{Ng} \&$ Kottelat, 1998

Pterocryptis cucphuongensis (Mai, 1978)

Clarias cavernicola Trewavas, 1936

Horaglanis krishnai Menon, 1950*

Uegitglanis zammaranoi Gianferrari, 1923

Phreatobius cisternarum Goeldi, 1905

Pimelodella kronei (Miranda-Ribeiro, 1907)

Rhamdia laticauda typhla Greenfield, Greenfield \&

Woods, 1982

Rhamdia macuspanensis Weber \& Wilkens, 1998

Rhamdia quelen (Quoy \& Gaimard, 1824)

Rhamdia reddelli Miller, 1984

Rhamdia zongolicensis Wilkens, 1993

Trichomycterus chaberti Durand, 1968

Trichomycterus conradii (Eigenmann, 1912)

Trichomycterus itacarambiensis Trajano \& de Pinna, 1996

Ancistrus cryptophthalmus Reis, 1987

Ancistrus formoso Sabino \& Trajano, 1997

Ancistrus galani Perez \& Viloria, 1994

Astroblepus pholeter Collette, 1962

Astroblepus riberae Cardona \& Guerao, 1994

Eigenmania vicentespelaea Triques, 1996

Amblyopsis rosae (Eigenmann, 1897)*

Amblyopsis spelaea DeKay, 1842

Chologaster agassizii Putnam, 1872

Speoplatyrhinus poulsoni Cooper \& Kuehne, 1974*

Typhlichthys subterraneus Girard, 1859

Lucifuga subterraneus Poey, 1858

Lucifuga teresinarum Díaz Perez, 1988

Lucifuga dentatus Poey, 1858

Lucifuga simile Nalbant, 1981

Lucifuga spelaeotes Cohen \& Robins, 1970

Ogilbia galapagosensis (Poll \& LeLeup, 1965)*

Ogilbia pearsei (Hubbs, 1938)*

Poecilia mexicana Steindachner, 1863

Monopterus eapeni Talwar in Talwar \& Jhingran, 1991

Monopterus roseni Bailey \& Gans, 1998

Ophisteron candidum (Mees, 1962)

Ophisteron infernale (Hubbs, 1938)

Milyeringa veritas Whitley, 1945

Oxyeleotris caeca Allen, 1996*

\section{A}

A

A

A

A

A

A

D

A

A

A

B

C

$\mathrm{C}$

B A

B D

B D

B A

B A

B A

B A

B A

C A

B $\quad$ B A

C $\quad$ C $\quad$ A

A $\quad$ B $A$

B $\quad$ A

B $A$

C $\quad A$

C $\quad$ A

C $A$

B A

B A

B D

B $B$

D $B$

B $B$

B $B$

B C

A $\quad$ B $\quad$ D

A $\quad$ B $\quad$ D

B $\quad$ C $\quad$ C

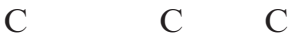

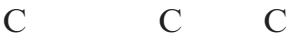

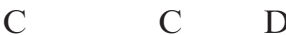

D $\quad$ B $\quad$ A

A $\quad$ C $\quad$ A

B $\quad$ B $\quad$ A

A $\quad$ B A

B $\quad$ B $\quad$ C

B $\quad$ B $\quad$ B 
TABle IV. Continued

\begin{tabular}{llll}
\hline Species & Pigment & Eyes & Scales \\
\hline Typhleotris madagascariensis Petit, 1933 & C & B & C \\
Typhleotris pauliani Arnoult, 1959 & A & B & C \\
Caecogobius cryptophthalmus Berti \& & B & B & B \\
Ercolini, 1991* & & & \\
Glossogobius ankaranensis Banister, 1994 & A & C & C \\
Lucigobius albus Regan, 1940 & A & C & A \\
Lucigobius pallidus Regan, 1940 & B & B & A \\
\hline
\end{tabular}

Absent, character is not expressed at all compared to normal; slight pigmentation, less than half the normal number of pigmented melanophores; mostly pigmented, more than half (but not 100\%) the normal number of pigmented melanophores; microphthalmic, eyes greatly reduced in size; sunken, eyes approximately normal size but covered by epidermal tissue; embedded scales, some scales present but embedded in or covered by skin; reduced scales, scales in normal position (covering the skin) but reduced in size; fully expressed, virtually indistinguishable from normal. The terms 'fully expressed' and 'normal' are in comparison with their epigean counterparts in the same family.

*Note that only the ten species marked with an asterisk exhibit the same level of development for all three character states.

all 86 species (upper bound of symmetrical 95\% CI is 8.48 species [by exact method; 7.59 by normal approximation]). The observed number, ten, is a minority of those species but is nevertheless about $2 \cdot 6$ times greater than expected (one-tailed $P<0 \cdot 01$, exact binomial calculation). So even though significantly more species with troglomorphic characters exhibit parallel development than expected by chance, uniform troglomorphic character development clearly does not typify this assemblage of species. The hypothesis of parallel evolution of troglomorphic characters in different species would predict a more uniform picture of expression of these troglomorphic attributes as each species responds to similar selective pressures, with differences among species primarily reflecting the time elapsed since they became hypogean. The evidence does not support this prediction.

3. Not all troglomorphism can be explained as a direct consequence of the absence of light. Reduction or loss of scales seems to be common (although not universal) among troglomorphic fishes (Banister, 1984). There are obvious candidates for selective pressures leading to depigmentation and reduction or loss of optic structures in darkness. These range from the cost of development to the potential for neoplasms, without compensating advantages of vision, signaling, or crypsis, as well as the possible accumulation of mutations that are no longer deleterious. On the other hand, a direct relationship of darkness to scale structure is obscure. Although loss of scales is a common feature among troglomorphic species, there are also many species of epigean fish lacking scales. Reduction of scales may yield greater sensitivity of the lateral line, but a literature search does not reveal an examination of this possibility nor any general explanation for the loss of scales in epigean fish.

Not only is the notion that troglomorphism is a definitive character of most hypogean fish species controverted by the evidence, but the characters also even 
vary among locations within species. Once again $A$. fasciatus may be drawn upon to illustrate this point.

The epigean form has a broad distribution in the freshwaters of the New World, from Texas to Argentina. Although cave populations of the eyed form have been reported in Belize (F. Bonaccorso, pers. comm.), Costa Rica (Romero, 1984), the Yucatán peninsula (Hubbs, 1938), and Brazil (Trajano, 2001), the only region with blind, depigmented individuals is the San Luis de Potosí Area, East Central Mexico (c. $22^{\circ} 05^{\prime} \mathrm{N}, 99^{\circ} 00^{\prime} \mathrm{W}$ ), where at least thirty-one caves supporting subterranean populations of this fish can be found (Espinasa et al., 2001). Not all the cave populations of this area display the same degree of morphological divergence from the surface forms, however. Some are completely blind and depigmented while others are only partially so. Three caves contain only individuals with full eyes and pigmentation. Eleven of these populations include blind, eyed, as well as phenotypically intermediate forms (Mitchell et al., 1977; Romero, 1983; Espinasa et al., 2001). Intermediate forms are not unique to A. fasciatus (Burr et al., 2001).

Besides blindness and depigmentation, the troglomorphic and surface morphs of $A$. fasciatus differ in many other morphological and behavioural characteristics. Troglomorphic populations have more taste buds (Schemmel, 1967). Unlike the epigean form, the blind hypogean form never schools, is active all the time, and is generally not aggressive (Breder \& Gresser, 1941; Breder, 1942; Boucquey et al., 1965; Erckens \& Weber, 1976). Under extreme laboratory conditions of food deprivation, Parzefall (2000) found aggressive behaviour in the troglomorphic form, but noted 'fish that were regularly fed showed the typical slow gliding through the water of the whole aquarium without aggressive encounters against conspecifics.'

Although the blind form produces an alarm substance, it does not respond to it (Pfeiffer, 1966). Schemmel (1980) reported differences in the angle of inclination when feeding from the bottom, with the blind form forming a more acute angle with the bottom. Even eyeless cave forms can respond to light, although the level of response differs depending on the population (Romero, 1985c). This variation in photoresponsiveness is not unique, with troglomorphic species of the North American cavefish family Amblyopsidae displaying different responses to light (Green \& Romero, 1997).

The surface and troglomorphic forms of $A$. fasciatus interbreed in natural and laboratory conditions, producing fertile hybrids with phenotypically intermediate forms in the $F_{1}$ generation, and an $F_{2}$ generation ranging from an almost completely blind and depigmented form to an almost eyed and pigmented one (Wilkens, 1969; Sadoglu, 1957; Peters \& Peters, 1973). Electrophoretic and karyotypic studies also support the contention that the cave and epigean forms are the same species (Avise \& Selander, 1972; Kirby et al., 1977). Recent molecular data (Dowling et al., 2002; Strecker et al., 2003), although suggesting separate invasion events for different troglomorphic populations of this species, still does not provide support for considering each population to be a species.

This biological picture is not only complicated in space but also in time. When the troglomorphic form of $A$. fasciatus was originally described in 1936, the entire population in the type locality, La Cueva Chica, consisted of a very uniform morph of blind and depigmented fishes. Romero (1983) analysed the gross morphology of 
individuals that had been collected between 1936 and 1942 as well as those collected in 1982. He found that the Cueva Chica population had evolved in 43 years or less into a morphologically intermediate population composed of individuals that were neither totally blind and depigmented nor fully eyed and pigmented. This new morph was ascribed to introgressive hybridization that probably started in 1940 with the invasion of the cave environment by epigean individuals. Langecker et al. (1991) later reported a similar case of introgressive hybridization for a cave population of $A$. fasciatus in La Cueva de El Pachón.

In other cases these rapid changes are the product of simple ecological replacement, such as reported for the hypogean population of Rhamdia quelen (Quoy \& Gaimard, 1824) in Trinidad, W.I. Based on their reduced eyes and pigmentation, these cave dwellers were originally described by Norman (1926) as a new troglomorphic genus and species, Caecorhamdia urichi (Norman, 1926). Later studies (Silfvergrip, 1996) indicated that this cave population was, taxonomically speaking, part of the widely distributed epigean (surface, eyed/pigmented) catfish $R$. quelen.

Beginning in the 1950s, a number of specimens collected in the cave displayed variability in eye size and pigmentation. In addition to field and laboratory studies (Romero \& Creswell, 2000; Romero et al., 2001), an examination of museum specimens suggested that the troglomorphic population had been completely replaced by an epigean one in as little as fifty years. This reinvasion of epigean individuals of $R$. quelen may have been facilitated by changes in precipitation patterns (Romero et al., 2002b). Epigean individuals, with their larger size, more aggressive behaviour, and generalist feeding nature, were well suited to outcompete troglomorphic individuals.

Based on all these factors, five general conclusions are that:

1. Only a minority of hypogean fishes are troglomorphic.

2. The expression of troglomorphic characters varies among species.

3. There is variation in troglomorphic character expression within species and populations.

4. A single species can show highly divergent phenotypic morphs that do not correspond perfectly with their environment, e.g., troglomorphism is not an inextricable consequence of cave-dwelling (as evidenced by fully eyed, pigmented hypogean fishes).

5. Troglomorphic populations can undergo rapid and dramatic phenotypic changes, due either to introgressive hybridization with, or ecological replacement by, conspecific epigean individuals.

The notion of troglomorphism being a unitary description for a species, and one characterizing most hypogean fishes, is therefore not supportable. One caveat of this conclusion is that the generalizations of variability within species come primarily from studies on $A$. fasciatus and, to a certain extent, on the family Amblyopsidae whose troglomorphic individuals seem to be quite genetically distinct from any presumed ancestor (see Romero, 2004, and references therein). The recent studies on $R$. quelen summarized above also suggest that diversity is the rule, not the exception, but these views of variability may be modified when more evidence is available.

In summary, essential ingredients of the assumptions underlying the concept of regressive evolution as applied to hypogean fishes are rejected. There is no 
evidence that initial cave colonization is an 'oops' phenomenon, but there is evidence that cave occupancy can be advantageous. Hypogean environments are not unusually harsh, most containing both abundant nutrients and breeding sites. There is a very large hypogean fauna. There is no evidence for preadaptations being necessary or sufficient attributes of successful colonizing taxa, a concept based on hypogean environments being harsh. A set of features alleged to characterize hypogean fishes, the troglomorphic characters, are extremely heterogeneous and often absent. So, the simple notion of the occasional species being accidentally entrapped in a harsh environment and surviving only because of its pre-adaptations, and then losing 'advanced' characteristics useful only with an epigean habit, is a caricature of the much more complex and varied picture.

Hypogean evolution is better characterized as simply another expression of ordinary neo-Darwinian evolution. There are advantages to behaviour that brings surface animals into caves or other hypogean habitats, and natural selection favors those that have a heritable component of this behavioural tendency. Once the behaviour is established, then other phenotypic variations that enhance success may also undergo selection. Characters such as pigmentation and optic systems may be reduced over time because they no longer confer advantages and may even be disadvantageous. Changes vary with characters and across species and even among populations of a species in a very heterogeneous fashion. In short, no special mechanisms or circumstances need to be invoked to explain hypogean evolution and its resulting variation.

Nevertheless, it cannot be denied that there are some unusual features to the evolution of hypogean fishes, particularly both the rapidity with which some changes occur and the persistence in single species of different epigean and hypogean morphs that are not necessarily genetically isolated. Next our attention is turned to mechanisms that may account for these features.

\section{PHENOTYPIC PLASTICITY}

Despite being an important evolutionary mechanism in modern neoDarwinian theory (Pigliucci, 2001), phenotypic plasticity is rarely mentioned in the biospeleological literature even though it plays a major role in the diversity of morphs and the evolution of cave fauna in general.

The array of phenotypes developed by a genotype over an array of environments (reaction norm), is genetically variable and this capacity for plasticity is therefore itself subject to natural selection (see Pigliucci, 2001, for a full discussion of this phenomenon). Those individuals with a heritable higher capacity to express specific adaptive traits under appropriate conditions can be expected to be favored by natural selection (Stearns, 1983). Phenotypic plasticity provides a reproductive advantage over a genetically fixed phenotype because environmentally induced phenotypes have a higher probability of conforming to prevailing environmental conditions than genetically fixed ones (Whiteman, 1994).

Caves around the world are known to represent a wide range of sizes as well as temperature and hydrological conditions (Juberthie, 2000). The only thing they have in common for most, if not all, of their length is the absence of natural light. The two most noticeable phenotypic characters closely correlated with 
illumination are eyes and pigmentation. Both casual observations and experimental studies are revealing that cave animals and their epigean ancestors can modify the development of their pigmentation and their visual apparatus in response to light conditions. Rasquin (1947, 1949) first reported for fish that when epigean $A$. fasciatus are raised under conditions of total darkness, they display less developed eyes and reduced pigmentation.

Similar observations for epigean crayfishes have also been reported (Cooper et al., 2001). On the other hand, if troglomorphic animals, even as adults, receive extended exposure to light, both pigmentation and the visual apparatus may become partially expressed, a finding that also holds for other troglomorphic fishes such as Typhlichthys subterraneus Girard, 1859 (Woods \& Inger, 1957), and $R$. quelen (Kenny in Romero et al. 2002b) in addition to A. fasciatus (Peters \& Peters, 1986).

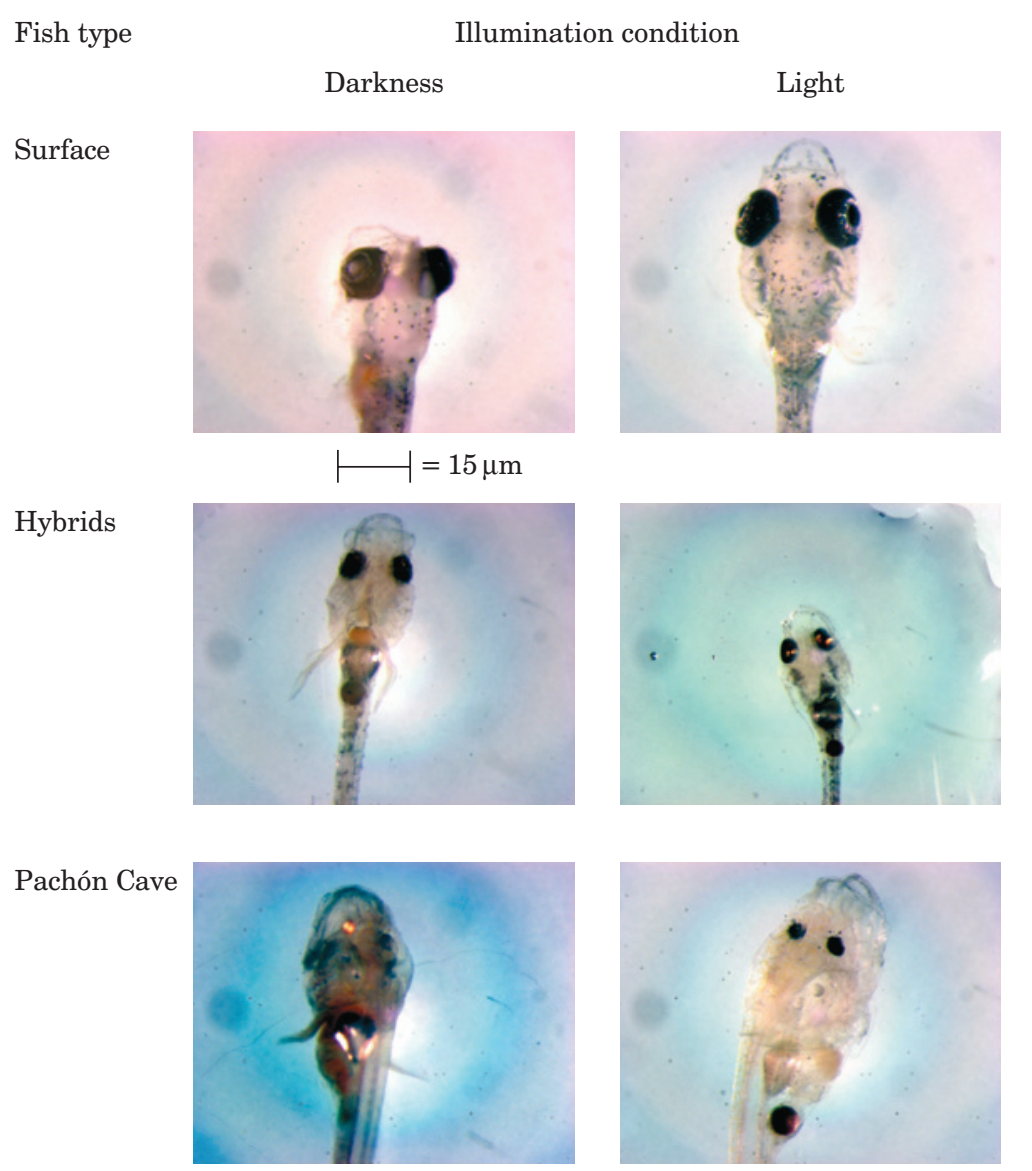

FIG. 1. Variation in developmental responses to light exposure of larval surface, cave, and hybrid Astyanax fasciatus. Larvae were reared in continuous darkness or continuous light for 30 days beginning when they were $24 \mathrm{~h}$ old. All three forms reveal an effect of light in the development of their eye tissues and the number of melanophores. The difference is particularly dramatic in the cave fish larvae. 
Effects of light exposure might be expected to be the most rapid and dramatic in association with growth. One-day old larvae from epigean $A$. fasciatus stock (eyed and pigmented) were therefore reared under conditions of continuous light or total darkness for 30 days. The eyes of those raised in darkness are much less developed than those raised in light. The more interesting contrast, however, is when larvae from La Cueva de El Pachón stock (blind and depigmented) are raised under the same two conditions. Under this regime, those reared in darkness do not have any apparent optic structures, as expected, but, remarkably, those raised under continuous illumination do (Fig. 1) (Romero et al., 2002).

Obviously this is not a case of neo-Lamarckism but of a well-described phenomenon of phenotypic plasticity expressed via reaction norm. Phenotypic plasticity, far from providing any support for any neo-Lamarckian view of evolution, has expanded neo-Darwinism by providing a framework for better understanding the effect of the environment on the phenotype, based on the fundamental maxim of genetics that phenotype = genotype + environment.

Clearly such results demonstrate that at least some troglomorphic forms differ from their epigean ancestors not necessarily in the genetic substrate for the troglomorphic characters, but rather, in part at least, from alternate developmental pathways that are dependent on environmental conditions, i.e., phenotypic plasticity. Such a conclusion is consistent with related observations that the absence of light can trigger heterochrony, i.e., changes in the timing of the development of features. Examples include cave organisms that are paedomorphs (animals that do not reach morphological maturity [metamorphs], reproducing as juveniles) and neotenes (animals with slowed growth) (sensu Gould, 1977) (Hobbs, 2000; Langecker, 2000; Weber, 2000). Further, most troglobitic salamanders are paedomorphic, and half of all known paedomorphic salamanders are troglomorphic (Bruce, 1979; Sweet, 1986). Paedomorphism in the hypogean environment may be advantageous if hydrological conditions are both variable and unpredictable. Paedomorphosis in Eurycea neotenes Bishop \& Wright, 1937, for example, seems to be a response to selection for the ability to pass dry periods in hypogean aquatic refugia (Sweet, 1977). Neoteny in hypogean animals, particularly fish, is associated with reduced body size (Poulson, 1964), loss of scales (Banister, 1984), fin modifications (Greenwood, 1976; Cooper \& Kuhene, 1974), and reduced ossification (Langecker \& Longley, 1993).

Natural selection may favor paedomorphs and neotenes by fixing the alleles underlying these variants of normal development in the cave population. Given that most cave populations are small and subject to very similar selective pressures within the same cave, this evolutionary process can take a relatively short period of time. Some evidence may suggest that paedomorphosis can be achieved via a major gene effect (small genetic change generating a large phenotypic effect) (Voss \& Shaffer, 1997; but see Voss \& Shaffer, 2000), helping to explain how salamander evolution into a paedomorphic condition can take place quite rapidly (Semlitsch \& Wilbur, 1989). Several authors (Yamamoto \& Jeffery, 2000; Jeffery, 2001; Strickler et al., 2001) have shown that troglomorphic characters in A. fasciatus can arise via minor changes in developmental genes, consistent with the notion that regulatory loci produce environment-specific genetic effects. 
Similar results have been reported for explaining pigment cell regression in cave A. fasciatus (McCauley et al., 2004). In addition, it has been shown that changes in regulatory genes have a major impact on the expression of pelvic and caudal fin precursors in threespine sticklebacks (Shapiro et al., 2004).

With few characters differing between epigean and troglomorphic forms, the rate of adaptation may be relatively high, an inverse statement of Orr's model that demonstrates a reduced rate of adaptation is a cost associated with increased complexity (Welch \& Waxman, 2003). Only when there is a constant gene flow from the epigean environment (such as introgression for $A$. fasciatus in La Cueva Chica or replacement for $R$. quelen in the Cumaca Cave, Trinidad, described earlier) can such changes be prevented. In this respect, the recessive allele can be considered a 'troglomorphic gene' because it manifests a morphologically and ecologically differentiated phenotype that is reproductively isolated from the epigean ancestor with genetic variance affected by environmental conditions.

This explanation is further supported by the convergent nature of troglomorphic characters. Convergent evolutionary patterns are strong evidence of adaptation via natural selection (Endler, 1986). Isolation would later lead toward speciation through genetic differentiation from the epigean ancestor. Many troglomorphic organisms are believed to have recently invaded the hypogean environment since their epigean ancestor is easily recognizable. The populations may even interbreed and produce fertile hybrids (Romero, 1983).

The application of the concept of phenotypic plasticity to the evolution of troglomorphic fishes in particular and troglomorphic organisms in general is suggested to help explain many of the phenomena summarized earlier in this paper.

A single genotype can produce a discrete series of phenotypes in the axolotl, Ambystoma mexicanum (Shaw \& Nodder, 1798). It is possible that some hypogean fish populations that exhibit only an incipient level of troglomorphism while sympatric with their epigean ancestor may offer parallel examples. The general troglomorphic similarities across a number of hypogean species and populations can be attributed to stabilizing selection for similar environments. The environmentally induced phenotypic range for a genotype is its norm of reaction. Such convergence can be the product of similar reaction norms rather than due to specific developmental mechanisms. Conversely, the overall differences found even among troglomorphic fishes in terms of eye, pigmentation, and scale development, must be the result of both differential reaction norm and local environmental conditions. Such variations are consistent with the heterogeneous nature of hypogean environments, particularly between tropical and temperate caves.

The evolution of troglomorphic characters across species does not necessarily occur in parallel because a) they are controlled by sets of genes independent from one another, b) the degree of development of some characters is conditioned by their phylogenetic history (e.g., barbel elongation in hypogean fish from families in which barbels are a common characteristic), and c) the selective pressures may differ from cave to cave (Culver et al., 1995). In addition to reduction or loss of some characters, many troglomorphic organisms exhibit enhancement of others, particularly those associated with chemical and mechanical sensory systems that are essential for forageing, mating, etc., in the absence of vision. 
Composite characters, like those often observed among troglomorphic organisms, may be produced by correlated phenotypic shifts that give the impression of a coevolved character set (West-Eberhard, 1989). Just as in the case of $A$. fasciatus, a species may, however, exhibit dramatically altered morphs, a virtual phenotypic revolution, with little overall genotypic change given the major effects produced by few alterations in regulatory genes.

In addition to instances of such phenotypic revolutions, both intraspecific variation in troglomorphisms as well as hypogean species that are not troglomorphic must also be accounted for. Ample genetic variation for phenotypic plasticity within natural populations is widespread, but it may vary both among traits and across species - some features being relatively fixed and others extremely plastic in response to the same environmental conditions. Some hypogean species or even local populations may therefore display, for example, a high degree of blindness but little depigmentation because the genes controlling these features offer different degrees of phenotypic plasticity. Such widespread genetic variation for phenotypic plasticity can help explain why, for example, cave populations of $A$. fasciatus only in the San Luis de Potosí area develop troglomorphisms while those in Yucatán, Belize, Costa Rica, and Brazil do not.

A genotype that enables phenotypic plasticity could yield what looks like an ecotype under extreme environmental conditions. An ecotype was originally defined as a genetic response to a specific habitat, i.e., populations that are genetically specialized to a particular environmental condition. Turning again to our best known example, A. fasciatus, although the epigean and troglomorphic phenotypes are drastically different and could lead to considering them as ecotypes, there is little genetic differentiation between them. The ability of troglomorphic individuals to regain some eye tissue and pigmentation when experimentally exposed to light illustrates the retention of a substantial capability for phenotypic plasticity even if under natural conditions they seem to represent an ecotype.

Plasticity is perhaps the most advantageous trait of all in fluctuating environments, especially when the range of and to some degree the timing of fluctuations have some predictability. Tropical caves undergo constant (but predictable) fluctuations in water levels due to drastic changes in rainfall regimes, perhaps offering one explanation for the greater prevalence of troglomorphic species and populations in the tropics than in temperate regions.

\section{THE ROLES PLAYED BY BEHAVIOUR AND GENETICS}

Although phenotypic plasticity has been considered in terms of morphological characters, it's important to remember that behaviour is the most plastic part of the phenotype.

The means by which behaviour, as opposed to accidental entrapment, for example, can play a major role in the colonization of cave environments has already been described. Although changes in behaviour are well documented and present even in transitional forms (Romero, 1984), the role played by behaviour in changes of other phenotypic characters is not known. Behavioural flexibility permits an individual to be in circumstances where a heritable variant in its physiology or morphology from the population-typical form may be advantageous. Such individual adaptability is the 
main object of selection (Wright, 1931). For this reason, behavioural changes usually precede external morphological evolution (Mayr, 1982; Wcislo, 1989; McPeek, 1995).

Behavioural invasion of a new environment by adults exposes their progeny to an environment that may yield different phenotypes (reaction norm) than those of the parents. In many such cases, hormones play a key role in the developmental processes and its constraints (Hayes, 1997). Environmental influences on both young animals and adults may yield changes as diverse as developmental aspects of cannibalistic structures and behaviour mediated by social contact in tiger salamanders (Hoffmann \& Pfennig, 1999), shifts in social status rapidly and reversibly affecting both colouration and brain structures in fish (Francis et al., 1993), and early locomotory experience affecting limb structure and hence adult locomotion in lizards (Losos et al., 2000). Although the mechanisms are complex and not yet fully understood, it's clear that behavioural adaptations both precede and have feedback interactions with differential regulation of developmental genes.

The next important step in understanding mechanisms underlying behaviourmediated effects on morphology is rooted in the molecular level of genetics. Epigenetic changes can enable cells to respond to environmental signals conveyed by hormones, growth factors, and other regulatory molecules without having to alter the DNA itself. Hormones, for example, can shape an organism's response to its genetic programming as well as carry information from environmental receptors. Both functions contribute to genotype-specific reactions that result in phenotypic plasticity. This rapidly developing field has concentrated on the variability in response of genes to a variety of environmental signals and to the circumstances surrounding the limitations of transcription of some genes to specific organs or tissues. Few studies have examined, directly or indirectly, the circumstances in which expression of genes can be silenced to yield reduction or loss of morphologic features.

When Yamamoto \& Jeffery (2000) surgically introduced normal lens tissue into larval troglomorphic $A$. fasciatus, resulting in the restoration of optic tissues that otherwise would not have been expressed, this finding was both striking and unexpected. Less noticed, however, was the result that lens tissue from a troglomorphic form transplanted into a host epigean fish retarded its eye growth and development. The optic structures associated with both troglomorphic and epigean phenotypes were found to be mediated by inductive signals from the lens. The loss of optic structure in these troglomorphs is not because the requisite genetic substrate is lacking, but rather the internal environment of an organ while development takes place has determined how that organ is shaped.

This study permitted another kind of examination of the link between behaviour and its physiological/morphological substrates. When the optic tissues in troglomorphic $A$. fasciatus are restored, is that sufficient to restore visual responses of a fish that otherwise would be blind?

This issue was investigated by examining phototactic behaviour in epigean and troglomorphic forms of $A$. fasciatus whose eyes were modified during embryogenesis by removing one or both lens vesicles from the epigean form or by transplanting the lens vesicle from an epigean fish into the optic cup of a blind cave form (Romero et al., 2003). Fish photoresponsiveness was examined by placing fish in an aquarium with one half illuminated and the other half dark, and scoring their presence in the illuminated or dark half. Both the eyeless 
epigean fish and cave fish with induced eyes appeared to be indifferent to the illumination, whereas the surface forms were scotophilic, suggesting that optic development and phototactic behaviour can be experimentally decoupled. Preliminary histology suggests that the epigean fish with a degenerate eye and cave fish with an induced eye both develop retinotectal projections while the size of their optic tectum is essentially unaffected.

These studies clearly show that an understanding of some basic questions in evolutionary biology requires an interdisciplinary approach that includes comparative studies, field work, behavioural observations and experiments, as well as reductionist approaches at the molecular level of gene regulation and development.

\section{ADDITIONAL CONSIDERATIONS}

Dobzhansky's (1970, pp. 405-407) very brief but illuminating discussion on phenotypic reductions in the context of cave organisms noted that: 1) evolution is opportunistic 2) adaptation to a new environment may decrease the importance of some organs/functions that may become vestigial and disappear, 3) there are numerous examples of plant and animals organs becoming rudimentary or lost, 4) acquisition or enlargement of organs can occur even with organisms that exhibit 'regressions' in other organs/functions, 5) cave animals provide some of the best examples of this phenomenon but some cave organisms do not display regressions and regressions may be found among non-cave animals, 6) there is a great deal of variation among these characters even within the same species/population, and 7) both genes and phenotypic plasticity are responsible for troglomorphic characters.

These assertions should not be surprising; this review is simply an updated amplification that is consistent with Dobzhansky's view and other neoDarwinian explanations, one in which it is emphasized that the notion of 'regressive evolution' does not help explicate or illuminate the evolution of troglomorphisms (see Romero, $1985 b$ for more discussion of the semantics).

Loss and/or reduction of phenotypic features in some hypogean fishes as well as other hypogean organisms are not rare. Less well recognized in the biospeleological literature is that such reductions and losses are also commonplace in a myriad of other taxa with limbless cetaceans and snakes, neotenic salamanders, and flightless island birds being obvious vertebrate examples. Nothing is uncommon about the phenomenon of reduction or loss of characters and biologists don't resort to the notion of regressive evolution in discussing it. Explanations range from the perspective of conservative ancestral characters and paedomorphism in salamanders (Collazo \& Marks, 1994) to exploring mechanisms of arrested development underlying limb loss in whales and other vertebrates (Bejder \& Hall, 2002; Shapiro et al., 2004). When loss of a tail and body hair, loss of the ability to synthesize Vitamin $\mathrm{C}$, reductions in the size of teeth and of the vermiform appendix, the thickness of the skull, and in the thickness of the bony brow ridges of human beings (Diamond \& Stermer, 1999) are discussed, the notion that our own species is a product of 'regressive evolution' is not introduced nor is it required in constructing realistic evolutionary scenarios. 
This perspective on the loss and reduction of phenotypic features is not to imply that there is a clear understanding of either the evolutionary or the underlying proximate mechanisms. Quite the contrary, studying mechanisms of loss may be at least as fruitful an approach to understanding both evolution and development as the more usual course of studying initial steps of appearance and elaboration of characters, particularly now that new advances in both molecular and behavioural biology are providing us with enhanced tools. In addition, by focusing on the variability present in hypogean fish, opportunities to incorporate the findings from evolution with those of phenotypic plasticity can be exploited, thereby also providing an appropriate conceptual framework to test new hypotheses. But the notion of 'regressive evolution' with its orthogenetic baggage is both unnecessary and potentially interferes with combining new reductionist approaches to the neo-Darwinian perspective.

K.M. Paulson read an earlier version of this paper and made valuable suggestions. Experiments on phenotypic plasticity were carried out at William Jeffery's lab at the University of Maryland. Stanley Weitzman provided information on the sensory system among characids. Helpful comments on both style and substance were contributed by Jennifer Ciaccio, Michael Robinson, Christy Wolovich, and two anonymous referees.

\section{References}

Agassiz, L. (1847) [1848]. [Plan for an investigation of the embryology, anatomy and effect of light on the blind-fish of the Mammoth Cave, Amblyopsis spelaeus]. Proceedings of the American Academy of Arts and Sciences 1, 1-180.

Agassiz, L. (1851). Observations on the blind fish of the Mammoth cave. American Journal of Science 11, 127-128.

Airoldi, L. \& Cinelli, F. (1996). Variability of fluxes of particulate material in a submarine cave with chemolithoautotrophic inputs or organic carbon. Marine Ecology Progress Series 139, 205-217.

Avise, J. C. \& Selander, R. K. (1972). Evolutionary genetics of cave-dwelling fishes of the genus Astyanax. Evolution 26, 1-19.

Banister, K. E. (1984). A subterranean population of Garra barreimiae (Teleostei: Cyprinidae) from Oman, with comments on the concept of regressive evolution. Journal of Natural History 18, 927-938.

Bardach, J. E., Todd, J. H. \& Crickmer, R. (1967). Orientation by taste in fish of the genus Ictalurus. Science 155, 1276-1278.

Bejder, L. \& Hall, B. K. (2002). Limbs in whales and limblessness in other vertebrates: mechanisms of evolutionary and developmental transformation and loss. Evolution and Development 4, 445-458.

Bellés, X. (1991). Survival, opportunism and convenience in the processes of cave colonization by terrestrial faunas. Oecologia Aquatica 10, 325-335.

Borowsky, R. B. \& Wilkens, H. (2002). Mapping a cave fish genome: polygenic systems and regressive evolution. Journal of Heredity 93, 19-21.

Boucquey, C., Thinès, G. \& Van Der Borght, C. (1965). Étude comparative de la capacité photopathique et de l'activité chez le poisson cavernicole Anoptichthys antrobius, chez la forme epigee ancestrale Astyanax mexicanus, et chez les hybrides $\mathrm{F}_{1}$ (Astyanax x Anoptichthys) et $\mathrm{F}_{2}$. In La distribution temporelle des activités animales et humaines (Mendioni, J., ed.), pp. 79-103. Paris: Masson et Cie.

Breder, C. M. (1942). Descriptive ecology of La Cueva Chica, with especial reference to the blind fish, Anoptichthys. Zoologica 27, 7-15.

Breder, C. M. \& Gresser, E. B. (1941). Correlations between structural eye defects and behavior in the Mexican blind characin. Zoologica 26, 123-131. 
Bruce, R. C. (1979). Evolution of paedomorphosis in salamanders of the genus Gyrinophilus. Evolution 33, 998-1000.

Burr, B. M., Adams, G. L., Krejca, J. K., Paul, R. J. \& Warren, Jr., M. L. (2001). Troglomorphic sculpins of the Cottus carolinae species group in Perry County, Missouri: distribution, external morphology, and conservation status. Environmental Biology of Fishes 62, 279-296.

Burt de Perera, T. (2004). Spatial parameters encoded in the spatial map of the blind Mexican cave fish, Astyanax fasciatus. Animal Behaviour 68, 291-295.

Chakraborty, R. \& Nei, M. (1974). Dynamics of gene differentiation between incompletely isolated populations of unequal sizes. Theoretical Population Biology 5, 460-469.

Chen, Y.-R., Yang, J.-X. \& Zhu, Z. G. (1994). A new fish of the genus Sinocyclocheilus from Yunnan with comments on its characteristic adaptation (Cypriniformes: Cyprinidae). Acta Zootaxonomica Sinica 19, 246-253.

Christiansen, K. A. (1992). Biological processes in space and time. Cave life in the light of modern evolutionary theory. In The Natural History of Biospeleology (Camacho, A. I., ed.), pp. 453-478. Madrid: Museo Nacional de Ciencias Naturales.

Collazo, A. \& Marks, S. B. (1994). Development of Gyrinophilus porphyriticus: identification of the ancestral development pattern in the salamander Family Plethodontidae. Journal of Experimental Zoology 268, 239-258.

Cooper, J. E. \& Kuhene, R. A. (1974). Speoplatyrhynus poulsoni, a new genus and species of subterranean fish from Alabama. Copeia 1974, 486-493.

Cooper, R. L., Li, H., Long, Y., Cole, J. L. \& Hopper, H. L. (2001). Anatomical comparisons of neural systems in sighted epigean and troglobitic crayfish species. Journal of Crustacean Biology 21, 360-374.

Culver, D. C. (1971). Analysis of simple cave communities. III. Control and abundance. American Midland Naturalist 85, 173-187.

Culver, D. C. \& Holsinger, J. R. (1992). How many species of troglobites are there? National Speleological Society Bulletin 54, 79-80.

Culver, D. C. \& Wilkens, H. (2000). Critical review of the relevant theories of the evolution of subterranean animals. In Subterranean Ecosystems (Wilkens, H., Culver, D. C. \& Humphreys, W. F., eds.), pp. 381-398. Amsterdam: Elsevier.

Culver, D. C., Kane, T. C. \& Fong, D. W. (1995). Adaptation and Natural Selection in Caves. The Evolution of Gammarus minus. Cambridge: Harvard University Press.

Darwin, C. (1859). On the origin of species by means of natural selection. London: J. Murray.

Darwin, C. (1861). On the origin of species by means of natural selection. London: J. Murray.

Deharveng, L. \& Bedos, A. (2000). The cave fauna of Southeast Asia. Origin, evolution and ecology. In Subterranean Ecosystems (Wilkens, H., Culver, D. C. \& Humphreys, W. F., eds), pp. 603-632. Amsterdam: Elsevier.

DeKay, J. E. (1842). Zoology of New York or the New-York Fauna, Part IV, Fishes. Albany, New York: W. \& A. White \& J. Visscher.

Diamond, J. \& Stermer, D. (1999). Evolving backward. Discover 19, 64-68.

Dobzhansky, T. (1970). Genetics of the Evolutionary Process. New York: Columbia University Press.

Dowling, T. E., Martasian, D. P. \& Jeffery, W. R. (2002). Evidence for Multiple Genetic Forms with Similar Eyeless Pheotypes in the Blind Cavefish, Astyanax mexicanus. Molecular Biology and Evolution 19, 446-455.

Endler, J. A. (1986). Natural Selection in the Wild. Princeton: Princeton University Press.

Erckens, W. \& Weber, F. (1976). Rudiments of an ability for time measurements in cavernicole fish Anoptichthys jordani Hubbs \& Innes (Pisces: Characidae). Experientia 32, 1297-1299.

Espinasa, L., Rivas-Manzano, P. \& Perez, H. E. (2001). A new blind cave fish population of genus Astyanax: Geography, morphology and behavior. Environmental Biology of Fishes 62, 339-344. 
Ferreira, R. L. \& Martins, R. P. (1999). Trophic structure and natural history of bat guano invertebrate communities, with special reference to Brazilian caves. Tropical Zoology 12, 231-252.

Francis, R. C., Soma, K. K. \& Fernald, R. D. (1993). Social regulation in the brainpituitary-gonadal axis. Proceedings of the National Academy of Sciences 90, 7794 7798.

Gilbert, J. \& Mathieu, J. (1980). Relations entre les teneurs en proteins, glucides et lipids au cours du jeone experimental, chez deux espáces de Niphargus peuplant des biotopes differents. Crustaceana (Supplement) 6, 137-147.

Gould, S. J. (1977). Ontogeny and Phylogeny. Cambridge: Harvard University Press.

Gould, S. J. (2002). The Structure of Evolutionary Theory. Cambridge: The Belknap Press of Harvard University Press.

Gould, S. J. \& Vrba, E. S. (1982). Exaptation- a missing term in the science of form. Paleobiology 8, 4-15.

Green, S. \& Romero, A. (1997). Responses to light in two blind cave fishes (Amblyopsis spelaea and Typhlichthys subterraneus) (Pisces: Amblyopsidae). Environmental Biology of Fishes 50, 167-174.

Greenwood, P. H. (1976). A new and eyeless cobitid fish (Pisces, Cypriniformes) from the Zagros Mountains, Iran. Journal of Zoology 180, 129-137.

Hayes, T. B. (1997). Hormonal mechanisms as potential constraints on evolution: examples from the Anura. American Zoologist 37, 482-490.

Hobbs, H. H. (2000). Crustacea. In Subterranean Ecosystems (Wilkens, H., Culver, D. C. \& Humphreys, W. F., eds), pp. 95-107. Amsterdam: Elsevier.

Hoch, H. \& Howarth, F. G. (1999). Multiple cave invasions by species of the planthopper genus Oliarus in Hawaii (Homoptera: Fulgoroidea: Cixiidae). Zoological Journal of the Linnean Society 127, 453-475.

Hoffman, E. A. \& Pfennig, D. W. (1999). Proximate causes of cannibalistic polyphenism in larval tiger salamanders. Ecology 80, 1076-1080.

Holsinger, J. R. (1976). The cave fauna of Pennsylvania. In Geology and biology of Pennsylvania caves (White, W. B. ed.), pp. 72-87. Harrisburg: Pennsylvania Geological Survey.

Holsinger, J. R. (2000). Ecological derivation, colonization, and speciation. In Subterranean Ecosystems (Wilkens, H., Culver, D. C. \& Humphreys, W. F., eds), pp. 399-415. Amsterdam: Elsevier.

Hose, L. D., Palmer, A. N., Palmer, M. V., Northup, D. E., Boston, P. J. \& DuChene, H. R. (2000). Microbiology and geochemistry in a hydrogen-sulphide-rich karst environment. Chemical Geology 69, 399-423.

Howarth, F. G. (1973). The cavernicolous fauna of Hawaiian lave tubes. Introduction. Pacific Insects 15, 139-151.

Howarth, F. G. (1981). Non-relictual terrestrial troglobites in the tropic Hawaiian caves. Proceedings of the $8^{\text {th }}$ International Speleological Congress of Speleology $\mathbf{2}$, 539-541.

Hubbs, C. L. (1938). Fishes from the caves of Yucatan. Carnegie Institution of Washington Publications 491, 261-295.

Humphreys, W. F. (1993). Cave fauna in semi-arid tropical Western Australia: a diverse relict wet-forest litter fauna. Memoires de Biospéologie 20, 105-110.

Hüppop, K. (2000). How do cave animals cope with the food scarcity in caves? In Subterranean Ecosystems (Wilkens, H., Culver, D. C. \& Humphreys, W. F., eds), pp. 159-188. Amsterdam: Elsevier.

Jeffery, W. R. (2001). Cavefish as a model system in evolutionary developmental biology. Developmental Biology 231, 1-12.

Jeffery, W. R., Strickler, A. G. \& Yamamoto, Y. (2003). To see or not to see: evolution of eye degeneration in Mexican blind cavefish. Integrative and Comparative Biology 43, 531-541.

Juberthie, C. (2000). The diversity of the karstic and pseudokarstic hypogean habitats in the world. In Subterranean Ecosystems (Wilkens, H., Culver, D. C. \& Humphreys, W. F., eds), pp. 17-39. Amsterdam: Elsevier. 
Juberthie, C. \& Ginet, R. (1994). France. In Encyclopaedia Biospeologica (Juberthie, C. \& Decu, V., eds), pp. 665-692. Moulis: Societé de Biosléologie.

Kirby, R. F., Thompson, K. W. \& Hubbs, C. (1977). Karyotypic similarities between the Mexican and blind tetras. Copeia 1977, 578-580.

Langecker, T. G. (1989). Studies on the light reaction of epigean and cave populations of Astyanax fasciatus (Characidae, Pisces). Memoires de Biospéologie 16, 169-176.

Langecker, T. G. (2000). The effects of continuous darkness on cave ecology and cavernicolous evolution. In Subterranean Ecosystems (Wilkens, H., Culver, D. C. \& Humphreys, W. F., eds), pp. 135-157. Amsterdam: Elsevier.

Langecker, T. G. \& Longley, G. (1993). Morphological adaptations of the Texas blind catfishes Trogloglanis pattersoni and Satan eurystomus (Siluriformes: Ictaluridae) to their underground environment. Copeia 1993, 976-986.

Langecker, T. G., Wilkens, H. \& Junge, P. (1991). Introgressive hybridization in the Pachon Cave population of Astyanax fasciatus (Teleostei: Characidae). Ichthyological Exploration of Freshwaters 2, 209-212.

Losos, J. B., Creer, D. A., Glossip, D., Goellner, R., Hampton, A., Roberts, G., Haskell, N., Taylor, P. \& Ettling, J. (2000). Evolutionary implications of phenotypic plasticity in the hindlimb of the lizard Anolis sagrei. Evolution 54, 301-305.

Marmonier, P., Vervier, P., Gilbert, J. \& Dole-Olivier, M.-J. (1993). Biodiversity in ground waters. Trends in Ecology and Evolution 8, 392-395.

Mayr, E. (1982). The growth of biological thought: diversity, evolution, and inheritance. Cambridge: Belknap Press.

McCauley, D. W., Hixon, E. \& Jeffery, W. R. (2004). Evolution of pigment cell regression in the cavefish Astyanax: a late step in melanogenesis. Evolution \& Development 6, 209-218.

McPeek, M. A. (1995). Morphological evolution mediated by behavior in the damselflies of two communities. Evolution 49, 749-769.

Mitchell, R. W., Russel, W. H. \& Elliot, W. R. (1977). Mexican eyeless characin fishes, genus Astyanax: environment, distribution, and evolution. Lubbock, TX: Texas University Press.

Mohr, C. E. (1953). Animals that live in Pennsylvania caves. National Society Speleological Bulletin 15, 15-23.

Nelson, J. S. (1994). Fishes of the world. New York: John Wiley \& Sons, Inc.

Norman, J. R. (1926). A new blind catfish from Trinidad, with a list of the blind cavefishes. Annals and Magazine of Natural History 18, 324-331.

Parzefall, J. (2000). Ecological role of aggressiveness in the dark. In Subterranean Ecosystems (Wilkens, H., Culver, D. C. \& Humphreys, W. F., eds), pp. 221-228. Amsterdam: Elsevier.

Peck, S. B. (1988). A review of the cave fauna of Canada, and the composition and ecology of the invertebrate fauna of caves and mines in Ontario. Canadian Journal of Zoology 66, 1197-1213.

Peters, N. \& Peters, G. (1973). Problemes genetiques de l'evolution regressive des cavernicoles. In Genetics and mutagenesis in fish (Schroeder, L. H., ed.), pp. 187-201. New York: Springer-Verlag.

Peters, N. \& Peters, G. (1986). Zur genetischen interpretation morphologischer gesetzmussigkeiten der degenerativen evolution. Untersuchungen am Auge einer hohlenform von Poecilia sphenops (Poeciliidae, Pisces). Zeitschrift für Morphologie und Ökologie der Tiere 62, 211-244.

Pfeiffer, W. (1966). Uber die vererbung des schreckreaktion bei Astyanax (Characidae, Pisces). Zeitschrift für Vererbungslehre 98, 97-105.

Pigliucci, M. (2001). Phenotypic plasticity. Beyond nature and nurture. Baltimore: The John Hopkins University Press.

Poly, W. J. (2001). Nontroglobitic fishes in Bruffey-Hills Creek Cave, West Virginia, and other caves worldwide. Environmental Biology of Fishes 62, 73-83.

Poulson, T. L. (1964). Animals in aquatic environments: animals in caves. In Handbook of Physiology (Dill, D. B., ed.), pp. 749-771. Washington, DC: American Physiological Society. 
Poulson, T. L. \& White, W. B. (1969). The cave environment. Science 165, 971-981.

Racovita, G. (2000). Ice caves in temperate regions. In Subterranean Ecosystems (Wilkens, H., Culver, D. C. \& Humphreys, W. F., eds), pp. 561-568. Amsterdam: Elsevier.

Rasquin, P. (1947). Progressive pigmentary regression in fishes associated with cave environments. Zoologica 32, 53-42.

Rasquin, P. (1949). Spontaneous depigmentation in the catfish Ameirus nebulosus. Copeia 1949, 246-251.

Reddell, J. R. (1982). A checklist of the cave fauna of Mexico. VII. Northern Mexico. Association Mexican Cave Studies Bulletin 8, 249-283.

Rogowitz, G. L., Candelaria, C. L., Denizard, L. E. \& Melendez, L. J. (2001). Seasonal reproduction of a neotropical frog, the cave coqui (Eleutherodactylus cooki). Copeia 2001, 542-547.

Romero, A. (1983). Introgressive hybridization in a population of Astyanax fasciatus (Pisces: Characidae) at La Cueva Chica. National Speleological Society Bulletin 45, 81-85.

Romero, A. (1984). Behavior in an 'intermediate' population of the subterranean-dwelling characid Astyanax fasciatus. Environmental Biology of Fishes 10, 203-207.

Romero, A. (1985a). Cave colonization by fish: role of bat predation. American Midland Naturalist 113, 7-12.

Romero, A. (1985b). Can evolution regress? National Speleological Society Bulletin 47, 86-88.

Romero, A. (1985c). Ontogenetic change in phototactic responses of surface and cave populations of Astyanax fasciatus (Pisces:Characidae). Copeia 1985, 1004-1011.

Romero, A. (1986). Charles Breder and the Mexican blind cave characid. National Speleological Society News 44, 16-18.

Romero, A. (1999). The blind cave fish that never was. National Speleological Society News 57, 180-181.

Romero, A. (2000). The speleologist who wrote too much. National Speleological Society News 58, 4-5.

Romero, A. (2001a). Evolution is opportunistic, not directional. BioScience 51, 2-3.

Romero, A. (2001b). Scientists prefer them blind: the history of hypogean fish research. Environmental Biology of Fishes 62, 43-71.

Romero, A. (2002). Between the first blind cave fish and the last of the Mohicans: The scientific romanticism of James E. DeKay. Journal of Spelean History 36, 19-29.

Romero, A. (2004). Pisces (Fishes): Amblyopsidae. In Encyclopedia of cave and karts Science (Gunn, J., ed.), pp. 595-597. New York: Fitzroy Dearborn.

Romero, A. \& J. Creswell. (2000). In search of the elusive 'eyeless' cave fish of Trinidad, W.I. National Speleological Society News 58, 282-283.

Romero, A. \& Lomax, Z. (2000). Jacques Besson, cave eels, and other alleged European cave fishes. Journal of Spelean History 34, 72-77.

Romero, A. \& Paulson, K. M. (2001). It's a wonderful hypogean life: a guide to the troglomorphic fishes of the world. Environmental Biology of Fishes 62, 13-41.

Romero, A., Singh, A., McKie, A., Manna, M., Baker, R. \& Paulson, K. M. (2001). Return to the Cumaca Cave, Trinidad, W.I. National Speleological Society News 59, 220-221.

Romero, A., Jeffery, W. \& Yamamoto, Y. (2002a). When cave fish see the light: reaction norm to light exposure during development in epigean, troglomorphic, and hybrids of Astyanax fasciatus. Abstract in : Program Book and Abstracts. Joint Meeting of Ichthyologists and Herpetologists. Kansas City, Missouri, p. 225.

Romero, A., Singh, A., McKie, A., Manna, M., Baker, R., Paulson, K. M. \& Creswell, J. E. (2002b). Replacement of the Troglomorphic population of Rhamdia quelen (Pisces: Pimelodidae) by an Epigean population of the same species in the Cumaca Cave, Trinidad, W.I. Copeia 2002, 938-942.

Romero, A., Green, S. M., Romero, A., Lelonek, M. M. \& Stropnick, K. C. (2003). One eye but no vision: troglomorphic Astyanax fasciatus (Pisces: Characidae) with induced eyes do not respond to light. Journal of Experimental Zoology (Molecular and Developmental Evolution) 300B, 72-79. 
Sadoglu, P. (1957). Mendelian inheritance in the hybrids between the Mexican blind cave fishes and their overground ancestor. Verhandlungen-Deutsche Zoologische Gesellschaft 1957, 432-439.

Sarbu, S. M. (2000). Movile Cave: A chemoautothrophically based groundwater ecosystem. In Subterranean Ecosystems (Wilkens, H., Culver, D. C. \& Humphreys, W. F., eds), pp. 319-343. Amsterdam: Elsevier.

Sarbu, S. M., Galdenzi, S., Menichetti, M. \& Gentile, G. (2000). Geology and biology of the Frasassi caves in central Italy: an ecological multi-disciplinary study of a hypogenic underground karst system. In Subterranean Ecosystems (Wilkens, H., Culver, D. C. \& Humphreys, W. F., eds), pp. 359-378. Amsterdam: Elsevier.

Schemmel, C. (1967). Vergleichende untersuchungen an den hautsinnesorganen ober-und unterirdisch lebender Astyanax -Formen, ein beitrag zur evolution der cavernicolen. Zeitschrift für Morphologie der Tiere 61, 255-316.

Schemmel, C. (1980). Studies on the genetics of feeding behaviour in the cave fish Astyanax mexicanus f. Anoptichthys. An example of apparent monofactorial inheritance by polygenes. Zeitschrift für Tierpsychologie 53, 9-22.

Schlagel, S. R. \& Breder, C. M. (1947). A study of oxygen consumption of blind and e eyed cave characins in light and darkness. Zoologica 32, 17-28.

Semlitsch, R. D. \& Wilbur, H. M. (1989). Artificial selection for paedomorphosis in the salamander Ambystoma talpoideim. Evolution 43, 105-112.

Shapiro, M. D., Marks, M. E., Peichel, C. L., Blackman, B. K., Nereng, K. S., Jónsson, B., Schluter, D. \& Kingsley, D. M. (2004). Genetic and developmental basis of evolutionary pelvic reduction in threespine sticklebacks. Nature 428, 717-723.

Silfvergrip, A. M. C. (1996). A systematic revision of the neotropical catfish genus Rhamdia (Teleostei, Pimelodidae). Stockholm: Swedish Museum of Natural History.

Sket, B. (1996a). The ecology of anchihaline caves. Trends in Ecology and Evolution 11, 221-225.

Sket, B. (1996b). Biotic diversity of hypogean habitats in Slovenia and its cultural importance. In Biodiversity. International Biodiversity Seminar (Cimerman, A. \& Gunde-Cimerman, N., eds), pp. 59-74. Ljubijana: National Institute of Chemistry.

Strickler, A. G., Yamamoto, Y. \& Jeffery, W. R. (2001). Early and late changes in Pax6 expression accompany eye degeneration during cavefish development. Development, Genes and Evolution 211, 138-144.

Stearns, S. C. (1983). The evolution of life-history traits in mosquitofish since their introduction to Hawaii in 1905: rates of evolution, heritabilities, and developmental plasticity. American Zoologist 23, 65-75.

Strecker, U., Bernatchez, L. \& Wilkens, H. (2003). Genetic divergence between cave and surface populations of Astyanax in Mexico (Characidae, Teleostei). Molecular Ecology 12, 699-710.

Sweet, S. S. (1977). Natural metamorphosis in Eurycea neotenes, and the generic allocation of the Texas Eurycea (Amphibia: Plethodontidae). Herpetologica 33, 364-375.

Sweet, S. S. (1986). Caudata. In: Stygofauna Mundi. A Faunistic, Distributional, and Ecological Synthesis of the World Fauna inhabiting Subterranean Waters (including the Marine Interstitial) (Botosaneanu, L., ed.). Leiden: E.J. Brill.

Tabuki, R. \& Hanai, T. (1999). A new sigillid ostracod from submarine caves of the Ryukyu Islands, Japan. Palaeontology 42, 569-593.

Thurgate, M. E., Gough, J. S., Spate, A. \& Eberhard, S. (2001a). Subterranean biodiversity in New South Wales: from rags to riches. Records of the Western Australian Museum Supplement 64, 37-47.

Thurgate, M. E., Gough, J. S., Clarke, A. K., Serov, P. \& Spate, A. (2001b). Stygofauna diversity and distribution in Eastern Australian cave and karst areas. Records of the Western Australian Museum Supplement 64, 49-62.

Trajano, E. (1995). Evolution of tropical troglobites: Applicability of the model of Quaternary climatic fluctuations. Memoires de Biospeleologie 22, 203-209.

Trajano, E. (2001). Ecology of subterranean fishes: an overview. Environmental Biology of Fishes 62, 133-160. 
Voss, S. R. \& Shaffer, H. B. (1997). Adaptive evolution via a major gene effect: Paedomorphosis in the Mexican axolotol. Proceedings of the National Academy of Sciences 94, 14185-14189.

Voss, S. R. \& Shaffer, H. B. (2000). Evolutionary genetics of metamorphic failure using wild-caught vs. laboratory axolotls (Ambystoma mexicanum). Molecular Ecology 9, 1401-1407.

Wcislo, W. T. (1989). Behavioral environment and evolutionary change. Annual Review of Ecology and Systematics 20, 137-169.

Weber, A. (2000). Fish and amphibia. In Subterranean Ecosystems (Wilkens, H., Culver, D. C. \& Humphreys, W. F., eds), pp. 109-132. Amsterdam: Elsevier.

Welch, J. J. \& Waxman, D. (2003). Modularity and the cost of complexity. Evolution 57, $1723-1734$.

West-Eberhard, M. J. (1989). Phenotypic plasticity and the origins of diversity. Annual Review of Ecology and Systematics 20, 249-278.

Whiteman, H. H. (1994). Evolution of facultative paedomorphosis in salamanders. Quarterly Review of Biology 69, 205-221.

Wilkens, H. (1969). Beitrage zur degeneration des auges bei cavernicolen, genzahl und manifestationsart. Zoologisches Anzeiger 180, 454-464.

Wilkens, H. (1979). Reduktionsgrad und phylogenetisches alter: ein beitrag besiedlungsgeschichte der limnofauna Yukatans. Zeitschrift fur Zoologische Systematik und Evolutionsforschung. 17, 262-272.

Wilkens, H., Culver, D. C. \& Humphreys, W. F. (Eds) (2000). Subterranean Ecosystems. Amsterdam: Elsevier.

Wright, S. (1931). Evolution in Mendelian populations. Genetics 16, 97-159.

Woods, L. P. \& Inger, R. F. (1957). The cave, spring, and swamp fishes of the family Amblyopsidae of the central and eastern United States. American Midland Naturalist 58, 232-256.

Yager, J. (1994). Speleonectes gironensis, new species (Remipedia, Speleonectidae), from anchialine caves in Cuba, with remarks on biogeography and ecology. Journal of Crustacean Biology 14, 752-762.

Yamamoto, Y. \& Jeffery, W. (2000). Central role for the lens in cave fish eye degeneration. Science 289, 631-633.

Zhang, C. (1986). On the ecological adaptation and geographical distribution of the barbine fish Varicorhinus (Scaphestes) macrolepis. Acta Zoologica Sinnica 32, 266-272. 